\title{
Decapod crustacean associations with scyphozoan jellyfish (Rhizostomeae: Pelagiidae) in the Southeastern Brazilian coast
}

\author{
Geslaine Rafaela Lemos Gonçalves ${ }^{1} \cdot$ Milena Regina Wolf $^{1} \cdot$ Rogerio Caetano da Costa ${ }^{2}$. \\ Antonio Leão Castilho ${ }^{1}$
}

Received: 3 November 2015 / Accepted: 5 March 2016 / Published online: 17 March 2016

(C) Springer Science+Business Media Dordrecht 2016

\begin{abstract}
In southeastern Brazil, decapod crustaceans were found living in association with the scyphozoan jellyfish. In total, 2002 specimens of the Scyphozoa Lychnorhiza lucerna were collected of which 511 were associated decapods that were identified as three species of the crab Libinia ferreirae, Libinia spinosa, and one Grapsoidea sp. and two species of caridean shrimps Periclimenes paivai and Leander paulensis. This is the first record of an association between the caridean shrimp L. paulensis and a scyphozoan and the first report of symbioses involving the crabs $L$. spinosa and Grapsoidea sp. on the Brazilian coast.
\end{abstract}

Keywords Brachyura $\cdot$ Crab $\cdot$ Caridea $\cdot$ Medusae . Symbiosis $\cdot$ Shrimp

\section{Introduction}

Associations of a benthic species with a pelagic organisms like the medusae of scyphozoan jellyfish can bring benefits such as greater mobility, shelter and food availability (Nogueira and Haddad 2005; Martinelli Filho et al. 2008; Sal Moyano et al. 2012; and Schiariti et al. 2012). Other potential advantages of symbiosis may include the exploitation

Antonio Leão Castilho

castilho@ibb.unesp.br

1 NEBECC (Group of studies on crustacean biology, ecology and culture), Department of Zoology, Institute of Biosciences of Botucatu, São Paulo State University, Botucatu 18618-970, Brazil

2 LABCAM (Laboratory of Biology and Ecology of Marine and Freshwater Shrimps), Department of Biology, Science Faculty, São Paulo State University, Bauru 17033-360, Brazil of new resources, the occupation of new ecological niches, refuges, and protection from predation (Thiel and Baeza 2001; Martinelli Filho et al. 2008; Sal Moyano et al. 2012).

Previous studies have documented associations of decapod crustaceans such as caridean shrimps (Palaemonoidea) (Marliave and Mills 1993; Moore et al. 1993; Martinelli Filho et al. 2008) and brachyuran crabs (Majoidea and Grapsoidea) (Nogueira and Haddad 2005; Sal Moyano et al. 2012; Schiariti et al. 2012) with scyphozoan in the medusoidphase. On the southern and southeastern coasts of Brazil, jellyfish, are accidentally captured as bycatch during trawlfishing for target species such as the seabob shrimp, Xiphopenaeus kroyeri (Heller, 1862) (Graça-Lopes et al. 2002; Schroeder et al. 2014). The capture of jellyfish, especially Rhizostomeae, potentially has an impact on any symbiotic species that are associated with them (Mianzan and Cornelius 1999). The community structure may thus be altered as a result of fishing influencing ability of symbionts to complete stages in their life cycle. The aim of the present study was to analyze and characterize the decapod species which live in association with scyphozoan medusae in southeastern Brazil.

\section{Materials and methods}

The medusoid-phase of scyphozoans and any associated crustaceans were sampled by trawling (30-min duration) using a shrimp boat outfitted with double-rig nets. The collections were done monthly in São Paulo state, Ubatuba $\left(23^{\circ} 35^{\prime} 00^{\prime \prime} \mathrm{S}\right.$ - $45^{\circ} 12^{\prime} 30^{\prime \prime} \mathrm{W}$, July 2013 to August 2014) and Cananéia $\left(25^{\circ} 04^{\prime} 43^{\prime \prime} \mathrm{S}-47^{\circ} 50^{\prime} 34^{\prime \prime} \mathrm{W}\right.$, February 2013 to May 2014), and Rio de Janeiro state, Macaé $\left(22^{\circ} 22^{\prime} 33^{\prime \prime} \mathrm{S}-41^{\circ} 46^{\prime} 30^{\prime \prime} \mathrm{W}\right.$, September 2013 to June 2014), at depths between 5 and $15 \mathrm{~m}$. A total of 216 trawls were executed (i.e., 48 in Macaé, 56 in 
Ubatuba and 112 in Cananéia). In order to standardize the results, the abundance of hosts and symbionts was estimated as the number of individuals caught per standard trawl set (catch per unit effort).

The bottom water was sampled using a Van Dorn bottle and the salinity was measured with an Atago S/1000 optic refractometer. The temperature $\left({ }^{\circ} \mathrm{C}\right)$ was measured using a thermometer attached to the Van Dorn bottle. The medusa collected were examined for the presence of any symbionts and identified with the help of Morandini et al. (2005) and Nogueira and Haddad (2006). Medusa without any symbionts were counted and returned to the sea. Those that had symbionts were individually packed in plastic bags and transported to the laboratory.

In the laboratory, whole jellyfish in good condition were examined macroscopically to check the anatomical location of symbiotic crustaceans. Medusae were measured between two rhopalia (an accuracy of $0.01 \mathrm{~mm}$ ) to assess the umbrella diameter (UD) (Nogueira and Haddad 2006) and were then grouped into $10 \mathrm{~mm}$ size classes. Umbrella diameters of medusae collected in the Cananéia region were compared with those from Macaé using the Kolmogorov-Smirnov two-sample test (Sokal and Rohlf 1995).

The decapod crustaceans were fixed in $70 \%$ alcohol and identified using Williams (1984); Melo (1996) and Tavares and Santana (2012) for Brachyura, Machado et al. (2010) and Chace (1969) for caridean shrimps and Pohle et al. (1999) for larvae. As a result of the difficulty in determining Libinia species because of their great similarities during the juvenile phases, we utilized a specific character on the dorsal surface of the thoracic sternum. In Libinia spinosa H. Milne Edwards, 1834, the thoracic episternites of IV-VII is armed with strong, posterolateral-projecting, broad teeth, a feature that is absent in the teeth of Libinia ferreirae Brito Carpello, 1871 (Tavares and Santana 2012).

The Brachyura were separated by sex, based on the abdomen shape for adults (elongated pattern for males and oval for females) and on the number of pleopods on individuals (two pairs for males and four pairs for females) (Almeida et al. 2013; Melo 1996). Both sexes were assessed for maturity by abdomen adherence to the thoracic sternite. Individuals were considered immature if the abdomen was sealed and cementing substances were present in the abdomen contour. Individuals with an unlocked abdomen were considered adults (for more details, see Gonçalves et al. 2016).

The sex of the Caridea were determined based on the presence or absence of appendices on the base of the endopod of the second pleopod, present in males but absent in females (Bauer 2004). The state of female sexual maturity was determined by the presence or absence of embryos attached to the pleopods.

The carapace width in Brachyura $(\mathrm{CW})$ and carapace length $(\mathrm{CL})$ in the Caridea were measured with a digital caliper to an accuracy of $0.01 \mathrm{~mm}$. Specimens smaller than $5 \mathrm{~mm}$ were measured with a stereo microscope (Zeiss ${ }^{\circledR}$ Stemi SV6, fitted with a Zeiss ${ }^{\circledR}$ Stemi $2000-C$ image capture system) with accuracy within $0.0001 \mathrm{~mm}$.

The proportion of jellyfish that had symbionts was estimated using an index: $\mathrm{P}=$ number of individuals with symbionts/ total individuals*100, and the density of symbionts per host was calculated as IMS = total number of symbionts/total number of hosts (Bush et al. 1997).

\section{Results}

\subsection{Abundance and richness of associated species}

A total of 2002 Lychnorhiza lucerna Haeckel, 1880 specimens were collected which had 511 associated decapod crustaceans from the three collecting areas. The crustaceans belonged to the Majoidea, Grapsoidea, and Palaemonoidea superfamilies. They comprised two species of Brachyura crabs Libinia ferreirae $(N=492)$ and L. spinosa $(N=1)$, one species of Grapsoidea crab $(N=1)$ and two species of caridean shrimps Periclimenes paivai Chace $1969(N=13)$ and Leander paulensis Ortmann, $1897(N=5)$ (Table 1, Fig. 1). It was not possible to identify the Grapsoidea because it was a small juvenile. More than one species of crustacean was sometimes present on the same medusae in the Cananéia region. Lychnorhiza lucerna was host to an average number of 1.55 and 1.06 symbionts in the Cananéia and Macaé areas, respectively and the frequency of finding medusa with symbionts was $22 \%$ and $19 \%$ respectively.

With respect to crab maturity, juveniles of $L$. ferreirae were found associated with medusae from Cananéia $(\mathrm{CW}=0.89 \mathrm{~mm}-36.8 \mathrm{~mm})$ and Macaé $(\mathrm{CW}=2.08 \mathrm{~mm}-$ $4.97 \mathrm{~mm}$ ) and adults in medusae from Cananéia $(\mathrm{CW}=40.17 \mathrm{~mm}-49.59 \mathrm{~mm})$. The specimens of $L$. spinosa and the Grapsoidea sp. were also juveniles (Table 1). With respect to shrimps, the majority of $P$. paivai were adult females carrying embryos $(N=11)$. Only one male was found. In contrast only males of $L$. paulensis were collected from Cananéia. In some cases, both caridean shrimp species were found sharing the same host in the Cananéia region. In two cases, two females of $P$. paivai carrying embryos (= ovigerous females) were observed sharing the same L. lucerna medusae. However no medusae was found to be host to a male-female pair.

A total of 1076 and 922 L. lucerna were collected in Macaé and Cananéia, respectively. Four L. lucerna from the Ubatuba region had decapod associates; but only one with an umbrella diameter (UD $=78 \mathrm{~mm}$ ) was associated with $L$. spinosa $(\mathrm{CW}=15.8 \mathrm{~mm}), 45 \%$ of the associations in Cananéia region were in large medusae with UD 80-130 mm. In Macaé, the $42 \%$ of the associations were found in medusae between 60 and $100 \mathrm{~mm}$ in size (Fig. 2). The sizes of L. lucerna in the two 
Table 1 Number of crustacean decapod species associated by jellyfish species for each region sampled in Brazilian southeastern coast

\begin{tabular}{|c|c|c|c|c|c|c|}
\hline \multirow[t]{2}{*}{ Region } & \multirow[t]{2}{*}{ Host } & \multirow[t]{2}{*}{ Decapod Sym } & \multirow[t]{2}{*}{ Sex of Sym } & \multicolumn{2}{|c|}{ Size range of carapace Sym } & \multirow[t]{2}{*}{$\mathrm{N}^{\circ}$ Sym } \\
\hline & & & & $<\mathrm{CW} / \mathrm{CL} \mathrm{mm}$ & $>\mathrm{CW} / \mathrm{CL} \mathrm{mm}$ & \\
\hline \multirow[t]{7}{*}{ 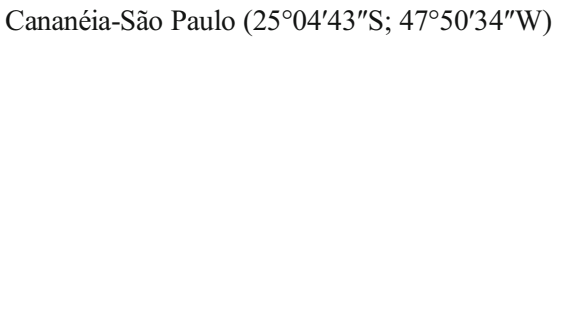 } & \multirow[t]{3}{*}{ L. lucerna } & \multirow[t]{3}{*}{ L. ferreirae } & $\mathrm{F}$ & 4.23 & 48.25 & 101 \\
\hline & & & M & 4.24 & 49.59 & 76 \\
\hline & & & - & 0.89 & 4.3 & 134 \\
\hline & L. lucerna & L. paulensis & M & 3.74 & 4.75 & 5 \\
\hline & \multirow[t]{2}{*}{ L. lucerna } & \multirow[t]{2}{*}{ P. paivai } & F ovg & 2.08 & - & 12 \\
\hline & & & M & 3.02 & 5.18 & 1 \\
\hline & L. lucerna & Grapsidea & - & 1.3 & - & 1 \\
\hline \multirow[t]{3}{*}{ Macaé-Rio de Janeiro $\left(22^{\circ} 22^{\prime} 33^{\prime \prime} \mathrm{S} ; 41^{\circ} 46^{\prime} 30^{\prime \prime} \mathrm{W}\right)$} & \multirow[t]{3}{*}{ L. lucerna } & \multirow[t]{3}{*}{ L. ferreirae } & $\mathrm{F}$ & 4.59 & 32.03 & 87 \\
\hline & & & M & 4.62 & 20.00 & 70 \\
\hline & & & - & 2.08 & 4.97 & 23 \\
\hline Ubatuba-São Paulo ( $\left.23^{\circ} 35^{\prime} 00^{\prime \prime} \mathrm{S} ; 45^{\circ} 12^{\prime} 30^{\prime \prime} \mathrm{W}\right)$ & L. lucerna & L. spinosa & $\mathrm{F}$ & 15.8 & - & 1 \\
\hline \multicolumn{6}{|l|}{ Total of animals associated } & 511 \\
\hline
\end{tabular}

Sym = symbionts; $\mathrm{M}=$ males; $\mathrm{F}=$ females; $\mathrm{F}$ ovg = ovigerous females $(-)$ unsexed animals; $\mathrm{CW}=$ carapace width; $\mathrm{CL}=$ carapace length; $\mathrm{N}^{\circ}=$ abundance of decapods by species/sex

regions was significantly different (Kolmogorov-Smirnov two-sample test; $\left.\mathrm{d}_{\max }=0.27, P<0.01\right)$.

In Macaé, $16 \%(N=169)$ of medusae carried a total of 180 juveniles crabs $(\mathrm{CW}=2.08 \mathrm{~mm}-32.03 \mathrm{~mm})$ in association, of which $73 \%$ were smaller than $10 \mathrm{~mm} \mathrm{CW}$. The highest incidence of medusae associated with crabs (134) was found in September 2012 (winter, temperature $21-22{ }^{\circ} \mathrm{C}$; Figs. 3 and $4 a$ ). During this period, the mean salinity was 38 . At this time there was the greatest abundance of L. ferreirae (85\% of the entire sample of associations). In January 2014 (summer, temperature $18.5-20^{\circ} \mathrm{C}$ and a mean salinity of 36.7 ), the medusae were also abundant $(N=329)$, but no associations were found (Figs. 3 and $4 a$ ).

In the Cananéia region, $22 \%$ of the captured medusae $(N=205, \mathrm{UD}=24-328 \mathrm{~mm})$ had 330 associated decapods.
The most abundant crustacean species was $L$. ferreirae $(N=311)$, composed mainly of juveniles (CW $=1.38 \mathrm{~mm}$ $36.8 \mathrm{~mm}$ ), with $76 \%$ of individuals being less than $10 \mathrm{~mm}$ $\mathrm{CW}$, and there were 4 megalopa larvae. Only $2 \%$ of these crabs were adults $(\mathrm{CW}=$ from 40.17 to $49.59 \mathrm{~mm}$ ). This region had medusae with up to 11 associated $L$. ferreirae as well as more than one species in the same host, for example, 1 L. ferreirae +1 L. paulensis, 3 L. ferreirae +1 P. paivai (females carrying embryos), and 6 L. ferreirae +1 Grapsidae. The average $\mathrm{CW}$ of crabs that shared each medusae was $4.21 \mathrm{~mm}$, which is smaller than the average $\mathrm{CW}$ of $7.8 \mathrm{~mm}$ for crabs captured alone in their host. The highest incidence of crabs associated with L. lucerna occurred during March 2014 (summer, temperature $25-26^{\circ} \mathrm{C}$ and salinity 34): 179 medusae were associated with 206 crabs. Some had more than one
Fig 1 a. Lychnorhiza lucerna Haeckel, 1880 and Libinia ferreirae Brito Capello, 1871 dorsal view; b. L. lucerna dorsal view with Periclimenes paivai Chance, 1969 (female carrying developing embryos attached beneath the abdomen) within the subgenital space of the medusa; $\mathbf{c}$. and d. L. ferreirae and Libinia spinosa H. Milne Edwards, 1834 dorsal pictures, respectively; e. Leander paulensis Ortmann, 1897 lateral view; f. P. paivai dorsal view; g. dorsal view of Grapsoidea MacLeay, 1838

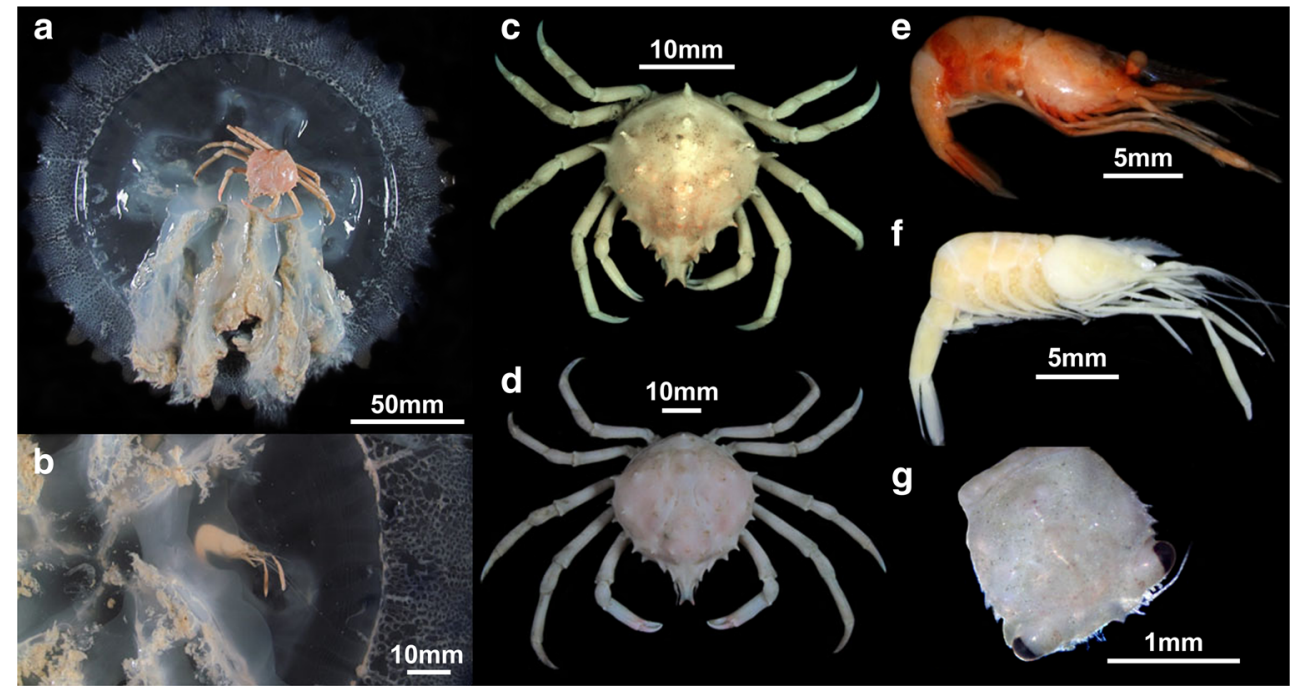




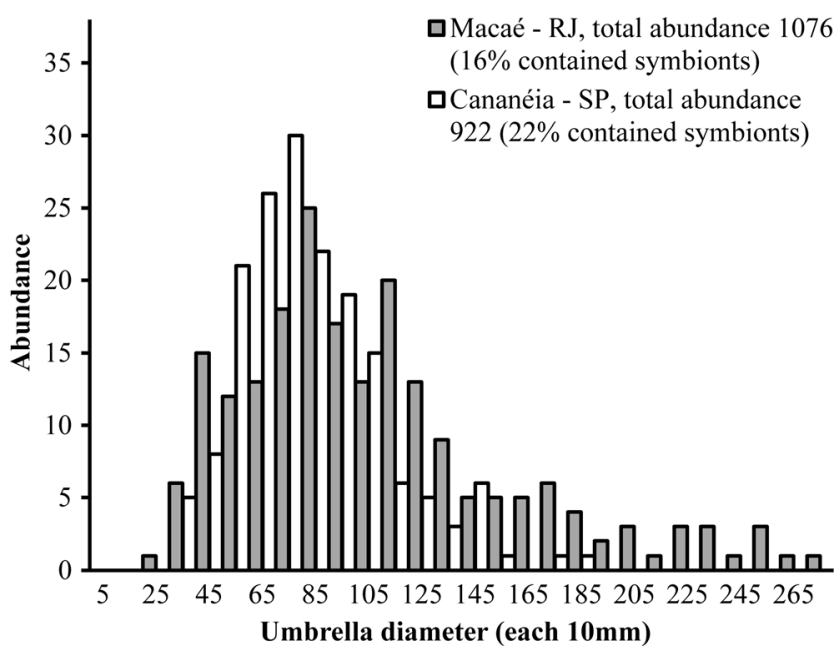

Fig 2 Size-frequency distributions for Lychnorhiza lucerna jellyfish with decapods associated from Cananéia, São Paulo, and Macaé, Rio de Janeiro, Brazilian southeastern coast. Intervals of 10-mm size class were used, ranging from 0 to 10 (class 5) to $>270$ (class 275)

symbiont in each host (Figs. 3 and $4 b$ ). The highest capture of 226 L. lucerna medusae was in August 2013 (winter, temperature $17.5-19{ }^{\circ} \mathrm{C}$ and salinity 29.2 ) (Figs. 3 and $4 b$ ) but only two medusae were host to four juvenile crabs (CW of 1.51 to $3.21 \mathrm{~mm})$.

\section{Discussion}

Morandini (2003) studied juvenile L. lucerna medusae in the Cananéia region, and observed the jellyfish bloom during the spring season. The initial ephyra phases develops into the medusa phase during the following season and the life span is 5-6 months (Schiariti 2008; Sal Moyano et al. 2012). It is after the ephyra phase, that the L. lucerna medusae becomes associated with decapod larvae (Sal Moyano et al. 2012).

The association of shrimps in the Palaemonidae family with Cnidarians has been reported previously, mainly with anemones (Omori et al. 1994; Fautin et al. 1995; AzofeifaSolano et al. 2014) but occasionally with the scyphozoan medusae (Moreira 1961; Martinelli Filho et al. 2008). In the present study of associations with L. lucerna, there was a predominance of adult $P$. paivai females carrying embryos. This has been observed by others (Martinelli Filho et al. 2008 and Ohtsuka et al. 2010).

In the present study, it is possible that female P. paivai incubating embryos adopt a sedentary behavior after reproduction and use their scyphozoan host as a means of protection for their offspring (Martinelli Filho et al. 2008). The females may disassociate from the hosts when larval are to be releases as the offspring could be a food source for the medusae (Bauer 2004).

Although the abundance of the shrimp, L. paulensis, was low in this study, it is the first record of an association with L. lucerna. Furthermore, little is known about this species, except that it is found in shallow waters up to $16 \mathrm{~m}$ deep on sandy bottoms and algae. The occurrence of only males in this association with L. lucerna in Cananéia could indicate a difference in behavior between the two shrimp species (RamosPorto 1986; Zimmermann et al. 2015).

Libinia ferreirae was the most abundant brachyuran crab species associated with $L$. lucerna, and they were predominantly juveniles which are not found freely on the ocean floor. Larval and juvenile individuals may be associated with jellyfish because the latter provide a protected environment during this most vulnerable period of their lives (Nogueira and Haddad 2005). Probably, these crabs colonize the medusae
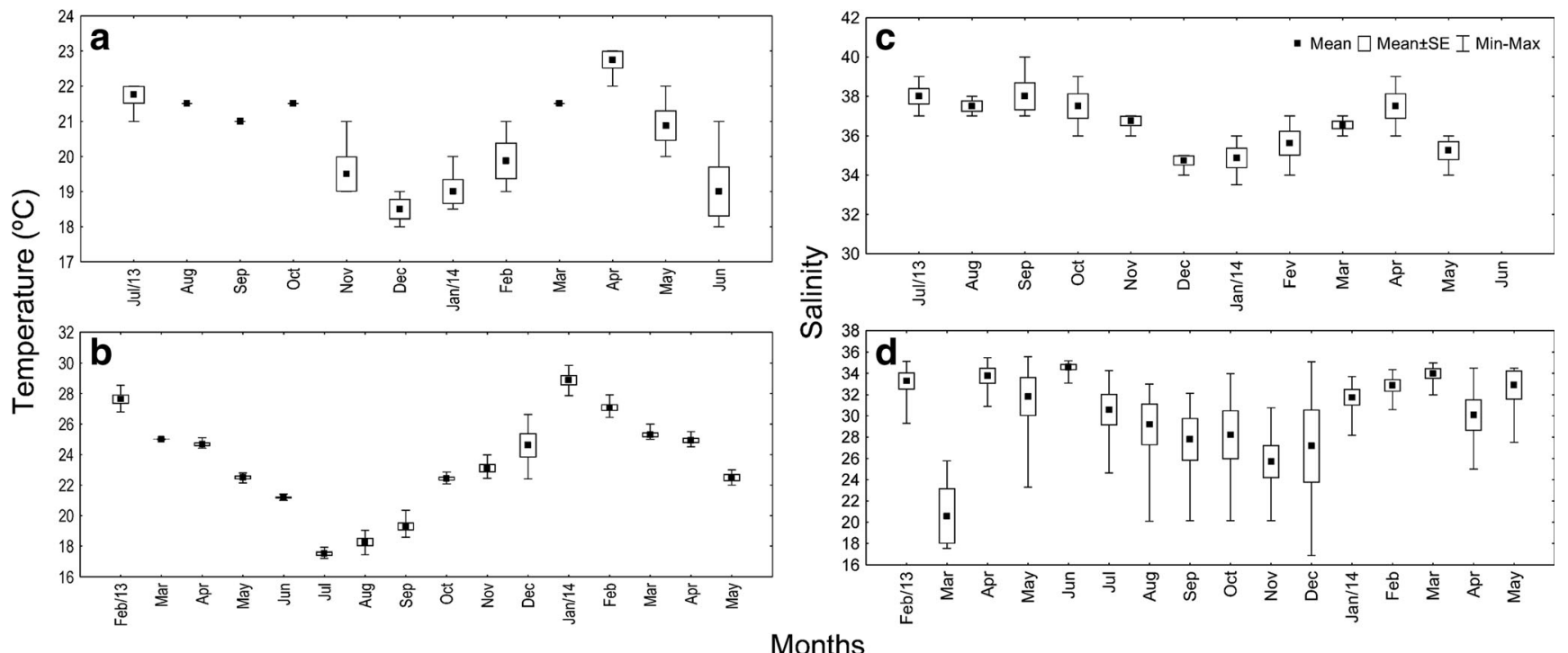

Fig 3 Monthly average temperature $\mathbf{a}, \mathbf{b}$ and salinity $\mathbf{c}, \mathbf{d}$ ) variations. a and c. Macaé, Rio de Janeiro state; b and d. Cananéia, São Paulo state, Brazilian southeastern coast. SE: Standard error; Min-Max: the minimum and maximum ranges 
Fig 4 Abundance of Lychnorhiza lucerna and Libinia ferreirae collected in Macaé a, Rio de Janeiro state, and Cananéia b, São Paulo state, Brazilian southeastern coast

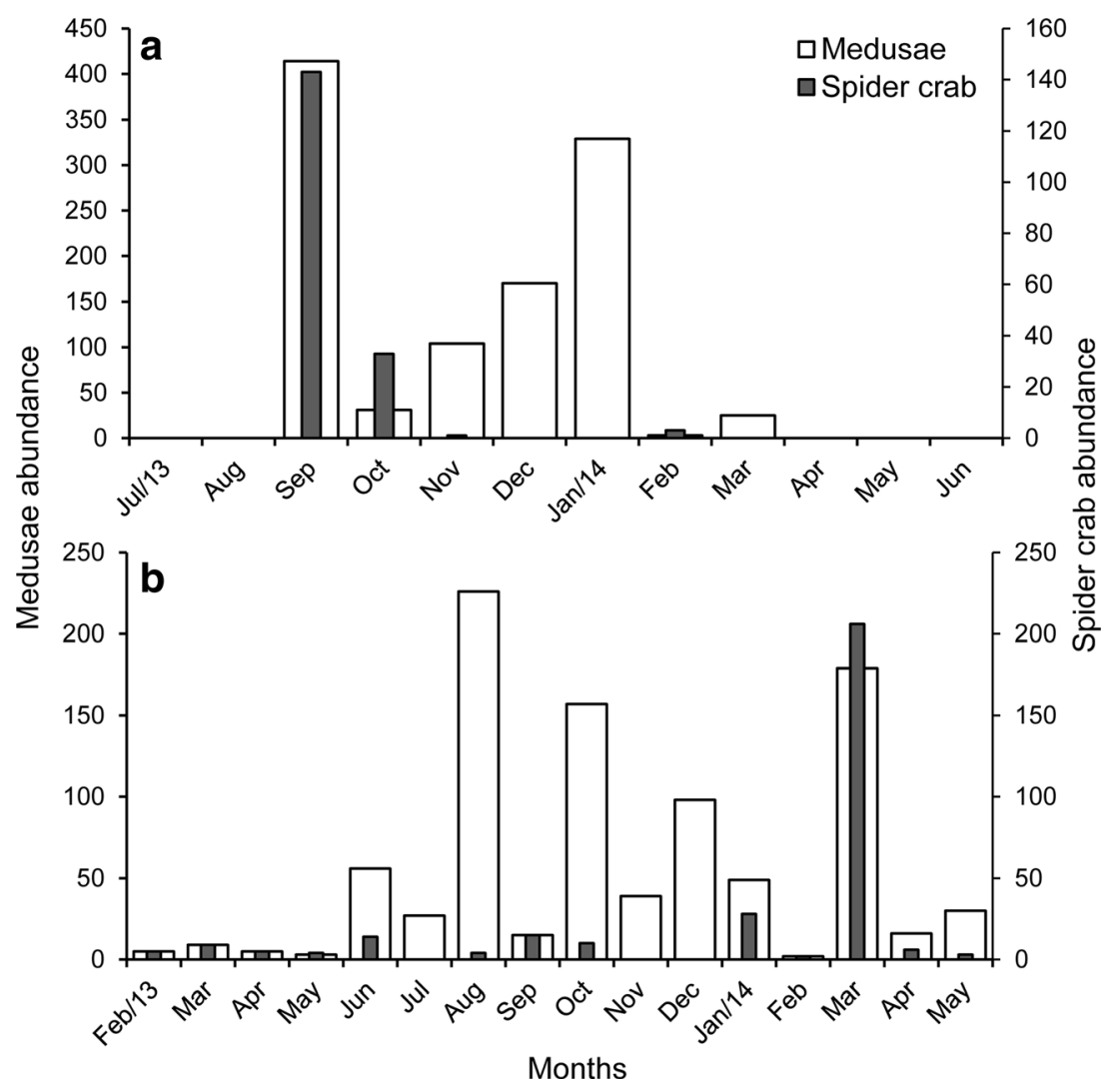

during their larval phases, they do so from the plankton (Gutsell 1928; Nogueira and Haddad 2005).

Jellyfish are highly mobile animals and this can be a disadvantage as they may be moved by sea currents to areas where the environmental conditions are unsuitable for any symbionts (Berggren 1994). In the present study, a greater abundance of $L$. ferreirae associated with medusae occurred during periods with high water temperatures. The lower abundance of L. ferreirae in Macaé during summer can be explained by cooler water derived from the cold ocean currents from the South Atlantic (South Atlantic Central Water) and intensified by upwelling (Campos et al. 2000; Acha et al. 2004). Lower temperatures are likely not favorable for these crustaceans as suggested by other studies (Hartnoll 2001; Nogueira and Haddad 2005; Sal Moyano et al. 2012). It is interesting that the wide salinity variation found between the three sites in the present study appeared not to influence the ability of crabs to associate with medusae.

Schiariti et al. (2012) also found individuals of the Grapsoidea superfamily together with Libinia sp. while another Grapsoidea, Planes major (MacLeay, 1838), has been found in association with other hosts as turtles (Pfaller et al. 2014). It has been suggested that they use the host to complete the life cycle when associated in the megalopa phase.

Commensalism seems to be the most likely relationship between the decapod crustaceans and L. lucerna. This relationship benefits one of the members without harming the other
(Parmentier and Michel 2013). Commensalism was proposed for L. ferreirae (Nogueira and Haddad 2005). However, the deep sea shrimp Notostomus robustus Smith, 1884 associated with the medusoid-phase of Atolla wyvillei Haeckel, 1880 (collected at a depth of $790 \mathrm{~m}$ ) feeds on the jellyfish umbrella so can be parasitic (Moore et al. 1993). Jachowski (1963) also considered the relationship between the crab Libinia dubia $\mathrm{H}$. Milne Edwards, 1834 and the jellyfish Aurelia aurita (Linnaeus, 1758) to be parasitism, while Shanks and Graham (1988) suggested that crabs prey on jellyfish gonads.

Our results corroborate that L. lucerna provide protection during the medusoid-phase for their pelagic crustacean associates during the most vulnerable phases (larvae, juveniles, females carrying embryos and post-molt individuals). Further research is needed to understand these associations and their role in marine ecosystems.

Acknowledgments The authors are indebted to Fundação de Amparo à Pesquisa do Estado de São Paulo" (FAPESP) for providing financial support during field collections and visiting activities (Biota/FAPESP \#2010/50188-8 and Scholarship \#2014/13770-1), CAPES CIMAR (No. 23038.004310/2014-85), and to CNPq (Financial Support \# 406006/ 2012-1, Research Scholarships PQ \# 305919/2014-8 and PQ 308653/ 2014-9). We thank many colleagues from the NEBECC group who helped with sampling and laboratory analyses; Dr. Maria Lucia Negreiros-Fransozo for useful suggestions and comments on early drafts of the manuscript; and the Instituto Brasileiro do Meio Ambiente e dos Recursos Naturais Renováveis (IBAMA) for granting permission to collect the shrimps. 


\section{References}

Acha EM, Mianzan HW, Guerrero RA, Favero M, Bava J (2004) Marine fronts at the continental shelves of austral South America physical and ecological processes. J Mar Syst 44:83-105

Almeida AC, Hiyodo CM, Cobo VJ, Bertini G, Fransozo V, Teixeira GM (2013) Relative growth, sexual maturity, and breeding season of three species of the genus persephona (decapoda: brachyura: leucosiidae): a comparative study. J Mar Biol Assoc UK 93:1581-1591

Azofeifa-Solano J, Elizondo-Coto M, Wehrtmann I (2014) Reproductive biology of the sea anemone shrimp Periclimenes rathbunae (caridea, palaemonidae, pontoniinae), from the Caribbean coast of Costa Rica. ZooKeys 457:211-225

Bauer RT (2004) Remarkable shrimps: adaptations and natural history of the carideans. University of Oklahoma, Oklahoma

Berggren M (1994) Periclimenes nomadophila and Tuleariocaris sarec, two new species of pontoniine shrimps (decapoda: pontoniinae), from Inhaca Island, Moçambique. J Crustac Biol 14:782-802

Bush AO, Lafferty KD, Lotz JM, Shostak AW (1997) Parasitology meets ecology on its own terms: Margolis et al. revisited. J Parasitol 83: $575-583$

Campos EJD, Velhote D, Silveira ICA (2000) Shelf break upwelling driven by Brazil current cyclonic meanders. Geophys Res Lett 27: 751-754

Chace FA (1969) A new genus and five new species of shrimps (decapoda: palaemonidae, pontoniinae) from the Western Atlantic. Crustaceana 16:251-271

Fautin DG, Guo CC, Hwang JS (1995) Costs and benefits of the symbiosis between the anemone shrimp Periclimenes brevicarpalis and its host Entacmaea quadricolor. Mar Ecol Prog Ser 129:77-84

Gonçalves GRL, Bolla Jr EA, Negreiros-Fransozo ML, Castilho AL (2016) Morphometric and gonadal maturity of the spider crab Libinia ferreirae brito capello, 1871 (decapoda: majoidea: epialtidae) at Southeastern Brazilian coast. J Mar Biol Assoc UK 1-7. doi:10.1017/S0025315416000370

Graça-Lopes R, Tomás ARG, Tutui SLS, Severino-Rodrigues E, Puzzi A (2002) Fauna acompanhante da pesca camaroneira no litoral do Estado de São Paulo, Brasil. Bol Inst Pesca 28:173-188

Gutsell JS (1928) The spider crab, Libinia dubia, and the jellyfish Stomolophus meleagris, found associated at Beaufort, North Carolina. Ecology 9:358-359

Hartnoll RG (2001) Growth in crustacea - twenty years on. Hydrobiologia 449:111-122

Jachowski R (1963) Observations on the moon jelly, Aurelia aurita, and the spider crab, Libinia dubia. Chesapeake Sci 4:195

Machado IF, Ferreira RS, Vieira RRR, D'incao F (2010) Leander paulensis Ortmann, 1897 e Periclimenes longicaudatus (stimpson, 1860 ) primeiros registros de caridea (crustacea, decapoda, palaemonidae) para o litoral de Santa Catarina, Brasil. Atlântica $32: 119-120$

Marliave JB, Mills CE (1993) Piggyback riding by pandalid shrimp larvae on hydromedusae. Can J Zool 71:257-263

Martinelli Filho JE, Stampar SN, Morandini AC, Mossolin EC (2008) Cleaner shrimp (caridea: palaemonidae) associated with scyphozoan jellyfish. Vie Milieu 58:133-140

Melo GAS (1996) Manual de identificação dos brachyura (caranguejos e siris) no litoral brasileiro. Ed. Plêiade, FAPESP, São Paulo

Mianzan HW, Cornelius PFS (1999) Cubomedusae and scyphomedusae. In: Boltovskoy D (ed) South Atlantic zooplankton, vol I. Backhuys Publishers, Leiden, pp. 513-559

Moore PG, Rainbow PS, Larson RJ (1993) The mesopelagic shrimp Notostomus robustus smith (decapoda: plophoridae) observed in situ feeding on the medusa Atolla wyvillei Haeckel in the
Northwest Atlantic, with notes on gut contents and mouthpart morphology. J Crustac Biol 13:690-696

Morandini AC (2003) Estrutura populacional de Chrysaora lactea e Lychnorhiza lucerna (cnidaria, scyphozoa) em amostras de plâncton, com a redescrição das espécies. Tesis. Instituto de Biociências da Universidade de São Paulo, São Paulo

Morandini AC, Ascher D, Stampar SN, Ferreira JFV (2005) Cubozoa e scyphozoa (cnidaria: medusozoa) de águas costeiras do brasil. Iheringia, Sér Zool 95:281-294

Moreira MGBS (1961) Sobre Mastigias scintillae Sp. nova (scyphomedusae, rhizostomeae) das costas do brasil. Bolm Inst Oceanogr S Paulo 11:5-29

Nogueira M Jr, Haddad MA (2005) Lychnorhiza lucerna (scyphozoa, rhizostomeae) and Libinia ferreirae brito capello (brachyura, majidae) association in Southern Brasil. Rev Bras Zool 22:908-912

Nogueira M Jr, Haddad MA (2006) Macromedusae (cnidaria) from the Paraná Coast, Southern Brazil. J Coast Res 39:1161-1164

Ohtsuka S, Kondo Y, Sakai Y, et al. (2010) In situ observations of symbionts on medusa occurring in Japan, Thailand, Indonesia and Malaysia. Bull Hiroshima Univ Mum 2:9-18

Omori K, Yanagisawa Y, Hori N (1994) Life-history of the caridean shrimp Periclimenes ornatus Bruce associated with a sea-anemone in Southwest Japan. J Crustac Biol 14:132-145

Parmentier E, Michel L (2013) Boundary lines in symbiosis forms. Symbiosis 60:1-5

Pfaller JB, Alfaro-Shigueto J, Balazs GH, et al. (2014) Hitchhikers reveal cryptic host behavior: new insights from the association between Planes major and sea turtles in the Pacific Ocean. Mar Biol 161: 2167-2178

Pohle G, Mantelatto FL, Negreiros-Fransozo ML, Fransozo A (1999) Larval decapoda (brachyura). In: Boltovskoy D (ed) South Atlantic zooplankton. Backhuys Publisher, Leiden, pp. 1282-1351

Ramos-Porto M (1986) Revisão das espécies do género Leander E. Desmarest que ocorrem no litoral brasileiro. Trab Oceanogr 19:7-26

Sal Moyano MP, Schiariti A, Gilberto DA, et al. (2012) The symbiotic relationship between Lychnorhiza lucerna (scyphozoa, rhizostomeae) and Libinia spinosa (decapoda, epialtidae) in the Río de La Plata (Argentina-Uruguay). Mar Biol 159:1933-1941

Schiariti A (2008) Historia de vida y dinámica de poblaciones de Lychnorhiza lucerna (scyphozoa) i Un recurso pesquero alternativo? Universidad de Buenos Aires, Thesis

Schiariti A, Sal Moyano MP, Giberto DA, Mianzan HW (2012) Primer registro de la asociación entre Lychnorhiza lucerna (scyphozoa, rhizostomeae) y Cyrtograpsus affinis (decapoda, varunidae). Lat Am J Aquat Res 40:1090-1093

Schroeder R, Branco JO, Freitas F Jr, Resgalla C Jr (2014) Preliminary assessment of the jellyfish bycatch captured off southern and Southeastern Brazil. Lat Am J Aquat Res 42:289-300

Shanks AL, Graham WM (1988) Chemical defense in a scyphomedusa. Mar Ecol Prog Ser 45:81-86

Sokal RR, Rohlf FJ (1995) Biometry. W. H, Freeman and Company, New York

Tavares M, Santana W (2012) On the morphological differentiation between Libinia spinosa and L. ferreirae (crustacea: brachyura: majoidea: epialtidae). Zoologia (Curitiba) 29:577-588

Thiel M, Baeza JA (2001) Factors affecting the social behavior of crustaceans living symbiotically with other marine invertebrates: a modelling approach. Symbiosis 30:163-190

Williams AB (1984) Shrimps, lobsters, and crabs of the Atlantic coast of the Eastern United States. Washington, Smithsonian Institution Press, DC (USA), Maine to Florida. Ed

Zimmermann U, Carvalho FL, Mantelatto FL (2015) The reproductive performance of the red-algae shrimp Leander paulensis (ortmann, 1897) (decapoda, palaemonidae) and the effect of post-spawning female weight gain on weight-dependent parameters. Braz J Oceanogr 63:207-216 